\title{
FORTIFICAȚII TEMPORARE ROMANE DIN MUNTENIA. O EVALUARE A CERCETĂRILOR RECENTE
}

\author{
OVIDIU ȚENTEA \\ VLAD CĂLINA \\ BOGDAN CONDURĂȚEANU \\ GEANINA BUTISEACĂ
}

\section{REZUMAT:}

Această lucrare este un raport de prezentare al ultimelor cercetări întreprinse asupra unor presupuse fortificații romane din regiunea Muntenia. Scopul acestei analize este de a actualiza informațiile despre aceste fortificații care erau situate între provinciile Moesia Inferior și Dacia. Cercetările de teren din Muntenia sunt incomplete, iar numărul fortificațiilor romane din această regiune este încă necunoscut. În timpul cercetărilor recente, au fost descoperite noi informații arheologice, ceea ce face oportună o revenire asupra unor discuții privind fortificațiile temporare romane - castra aestiva.

Incintele prezentate au fost identificate prin colectarea de date de teren, măsurători, fotografii din dronă, fotografii aeriene și imagini din satelit, care au fost apoi coroborate cu informațiile disponibile la acel moment în arhive.

\section{Abstract: Roman CAMPS in Muntenia. A REview of ReCENT RESEARCH}

This paper is a report presenting the latest research carried out on alleged Roman fortifications in the region of Muntenia. The aim of this review is to update the information about these fortifications which were located between the provinces of Moesia Inferior and Dacia. Field surveys in Muntenia are incomplete and the number of Roman fortifications in this region is still unknown. During recent research, new archaeological information has been uncovered, making it appropriate to revisit some of the discussions on Roman camps - castra aestiva.

The enclosures presented were identified by collecting field data, topographic measurements, drone photographs, aerial photographs and satellite imagery, which were then corroborated with information available at that time in the archives.

CUVINTE CHEIE: Armata romană, castre temporare, fotografii din dronă, fotografii aeriene și imagini din satelit.

KEYWORDS: Roman Army, camps, drone images, aerial photographs and satellite imagery.

Constituirea frontierei romane în zona gurilor Dunării este o temă de actualitate, în plină dezbatere. În cursul unor cercetări recente au apărut informații arheologice noi, care au făcut oportună revenirea asupra unor discuții referitoare la fortificațiile romane cu caracter temporar. În contextul studierii detaliate a frontierelor romane din România $^{1}$, am analizat anumite puncte de interes din Muntenia, teritoriu aflat între provinciile Moesia Inferior și Dacia $^{2}$.

Amplasarea fortificațiilor romane din nord-vestul Munteniei a fost interpretată din câteva perspective. În mod tradițional au fost văzute ca (1) posibile trasee pe care s-ar fi deplasat armatele romane în cursul campaniilor dacice, (2) fortificațiile în cauză ar fi marcat traseul armatei romane în cursul primei campanii împotriva dacilor (101-102 p. Chr.) în urma anihilării principalelor fortificații dacice 3 , fie (3) acestea ar fi avut rolul de a bloca toate văile care constituiau căi de acces spre Transilvania ${ }^{4}$. Într-un studiu de dată mai recentă, Mihail Zahariade a revenit asupra unor scenarii istorice prin care propunea (4) trasee pe care legiunea XI Claudia se deplasa prin Câmpia Munteniei către

\footnotetext{
Programul Naţional LIMES - https://limesromania.ro.

2 Tema a fost discutată într-un studiu recent, în curs de publicare (Țentea și Matei-Popescu 2021), precum și în cadrul unui proiect comun de studiere a impactului armatelor romane dislocate în nord-vestul Munteniei - Țentea şi Matei-Popescu 2015, 2016.

3 Zahariade și Dvorski 1997; Zahariade 2006.

4 Petolescu 1983, 510-514.
} 


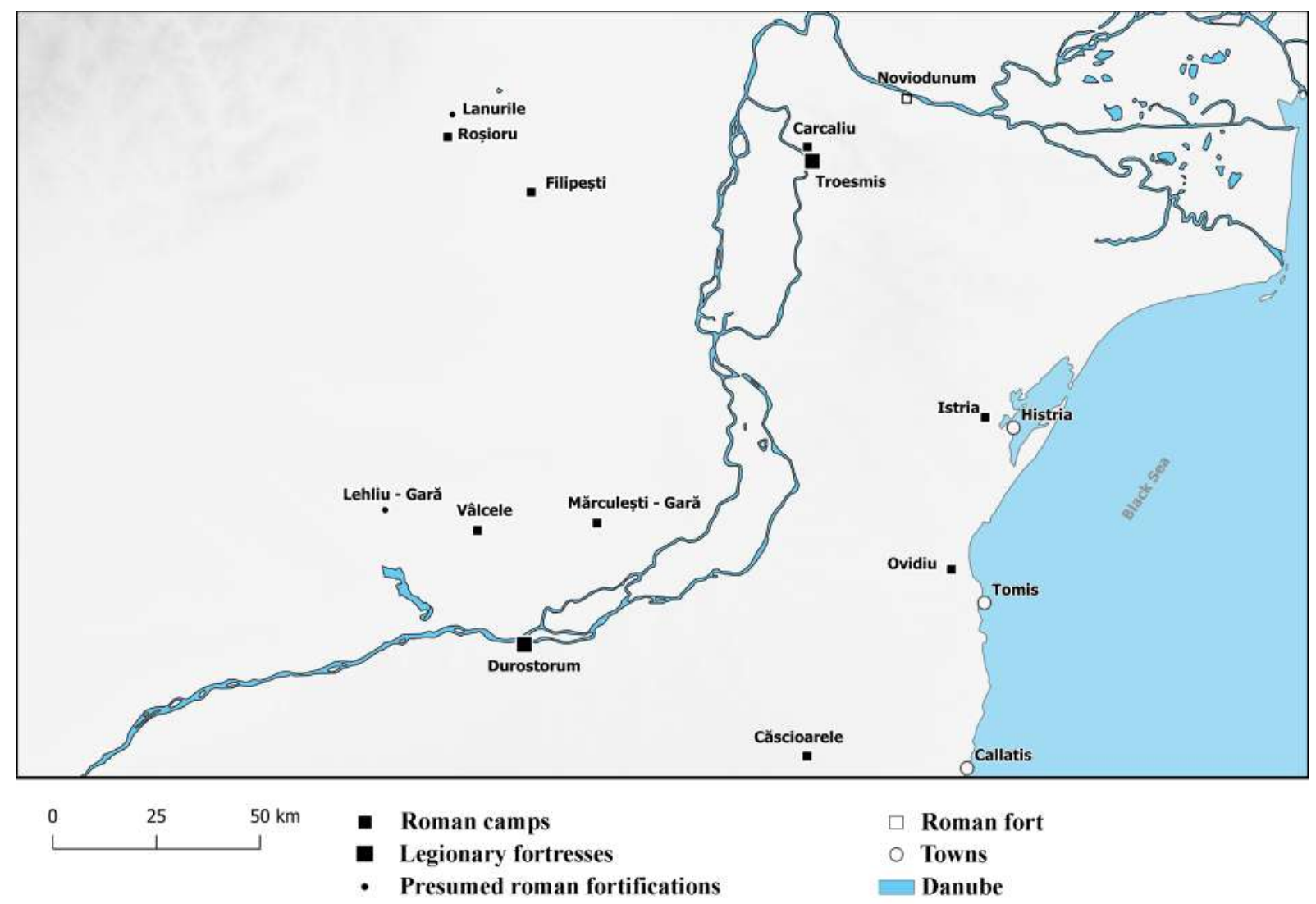

01. Harta presupuselor fortificații romane din Muntenia.

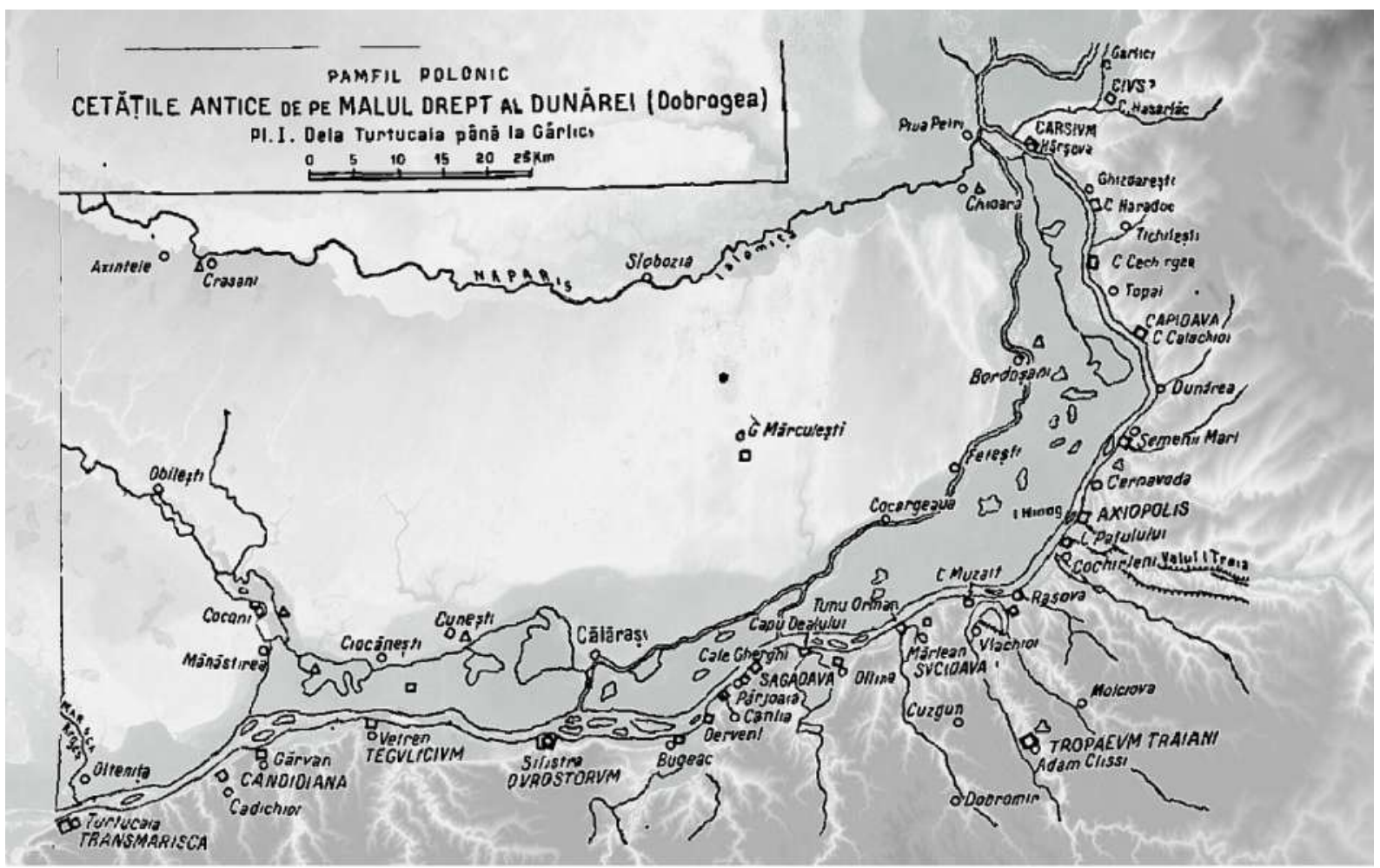

02. Harta lui Pamfil Polonic suprapusă peste modelul digital al terenului (Polonic, P., Cetățile antice de pe malul drept al Dunării (Dobrogea) până la gurile ei, În: Revista „Natura”, nr. 7, 15 iulie 1935, pg. 21). 
zona de nord-vest, argumentând această ipoteză pe baza semnalărilor unor fortificații temporares . Menționarea unor posibile fortificații temporare romane pe teritoriul Munteniei, insuficient documentate la acea dată, a fost făcută de Ioana Bogdan-Cătănciu cu ocazia publicării rezultatelor preliminare din fortificația de la Rucăr6.

În zona curburii Carpaților, pe unul dintre traseele care asigura comunicarea dintre Transilvania şi Muntenia, au fost semnalate recent câteva descoperiri interesante de fortificații romane de marș care detaliază semnificativ rutele pe care le-au parcurs armatele romane, cel mai probabil în timpul campaniilor de cucerire a Daciei ${ }^{7}$. Într-un raport al stadiului cercetării frontierei dunărene au fost incluse și semnalările a două noi fortificații romane temporare din Dobrogea $^{8}$. Într-o sinteză recentă a castrelor temporare din arealul Dunării de Jos, au fost formulate câteva posibile explicații pentru amplasarea unor castre temporare de dimensiuni mari din Dobrogea, făcând câteva referiri şi la descoperirile de pe teritoriul Munteniei, incluse în acest raport ${ }^{9}$, la care vom adăuga şi alte descoperiri recente.

Informațiile despre castrele temporare au fost, până nu demult, lacunare, fiind prin urmare puțin relevante pentru acest spațiu. Aceste structuri necesită o analiză detaliată pentru a putea formula concluzii pertinente, pe baza cărora se pot construi scenarii credibile despre mişcările trupelor romane. Discuțiile cele mai interesante despre terminologie sau despre explicarea modului în care au funcționat aceste castre, s-au purtat, nu întâmplător, în mediul academic britanic, spațiu în care au fost documentate numeroase fortificații de acest tip. Clasificarea castrelor temporare, devenită clasică, cuprinde patru categorii funcționale: castre de marș, castre de antrenament, castre de asediu sau castre de construcție ${ }^{10}$. Dinamica armatelor romane în cursul invaziilor a fost urmărită prin distribuția spaţială a castrelor temporare, dar în cazul nostru este nevoie de informații suplimentare pentru a ajunge la formularea unor scenarii relevante.

Fără a intra de această dată în discuția privitoare la castrele romane de pe teritoriul Munteniei, subiect pe care 1-am tratat parțial într-un studiu de dată relativ recentă ${ }^{11}$, ne propunem să facem o trecere în revistă succintă a celor mai recente descoperiri ale unor castre de marș din estul Munteniei, în arealul cuprins între Durostorum ${ }^{12}$ și zona Carpaţilor de Curbură: Vâlcele (jud. Călărași), Mărculeşti-Gară (jud. Călărași), Filipeşti (jud. Brăila), Roșioru (jud. Buzău) și Lanurile (jud. Buzău).

Castrul temporar descoperit pe fotografiile satelitare la Vâlcele (aparţine administrativ de com. Alexandru Odobescu, jud. Călărași) (fig. 3-4) se află la 29 km NNV, în linie dreaptă de castrul de la Durostorum (Silistra), adică la o distanță de o zi de marș. Dimensiunile castrului sunt $520 / 530 \times 350 \mathrm{~m}(18,6 \mathrm{ha})^{13}$, iar orientarea este aproximativ NE-SV. Conturarea se face printr-o dungă albicioasă continuă, provenind de la valul de incintă. Nu se observă conturul mai închis la culoare care ar corespunde în exterior cu şanțul fortificației. De asemenea, nu se pot observa întreruperi care să marcheze localizarea porților sau alte structuri constructive. În interiorul fortificaţiei nu se disting alte elemente de compartimentare internă. În proximitatea vestică, la $60 \mathrm{~m}$ de latura vestică, se conturează (mai pronunţat decât fortificaţia mare) o incintă aproximativ pătrată, cu latura de $50 \mathrm{~m}^{14}$. Conturul îngroșat albicios poate reprezenta șanțurile care delimitau un tumul aplatizat în ultimele decenii datorită lucrărilor agricole intensive ${ }^{15}$.

\footnotetext{
Zahariade 2018 .

Bogdan-Cătăniciu 1974, 284-286 fig. 6.

Ştefan și Ştefan 2018.

Țentea et al. 2019, 69-75.

Țentea şi Matei-Popescu 2021.

Jones 2017, 522-523.

1 Țentea şi Matei-Popescu 2015, 109-130.

Pentru staționarea legiunii XI Claudia la Durostorum vezi pe larg discuția din Matei-Popescu 2010, 133-141.

3 Oltean și Hanson 2015, 995 fig. 4a; Țentea și Matei-Popescu 2021.

14 În cazul în care acestea ar fi fost două fortificații contemporane, n-ar fi fost exclus ca fortificația mai mică să fi fost castru de antrenament - Jones 2017, 522-523.

15 Pentru cea mai recentă discuție detaliată și o punere în context istoric vezi Bârcă 2020, 326-332

03. Vâlcele, localizarea fortificației.
}

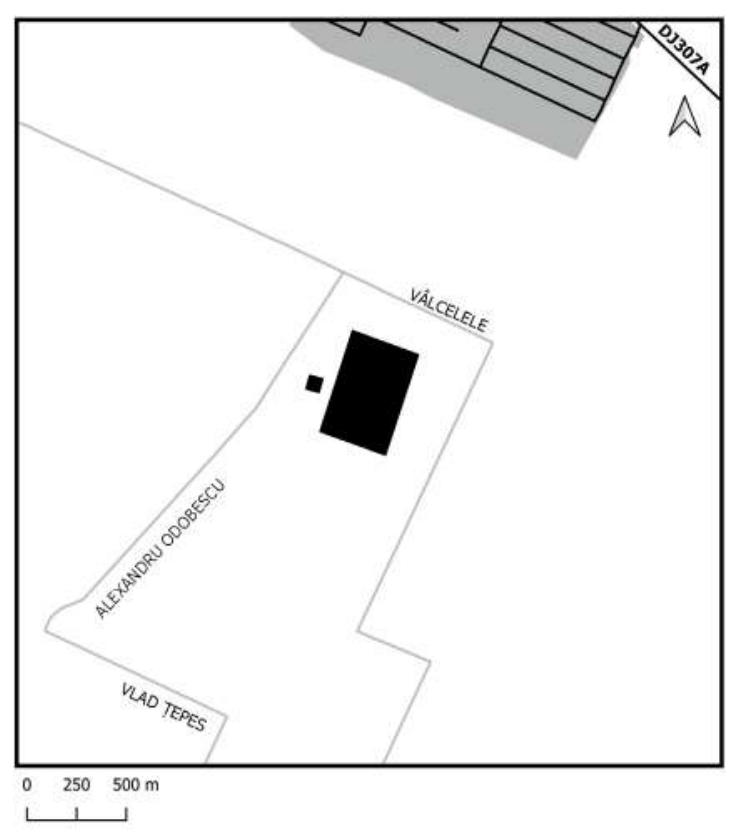




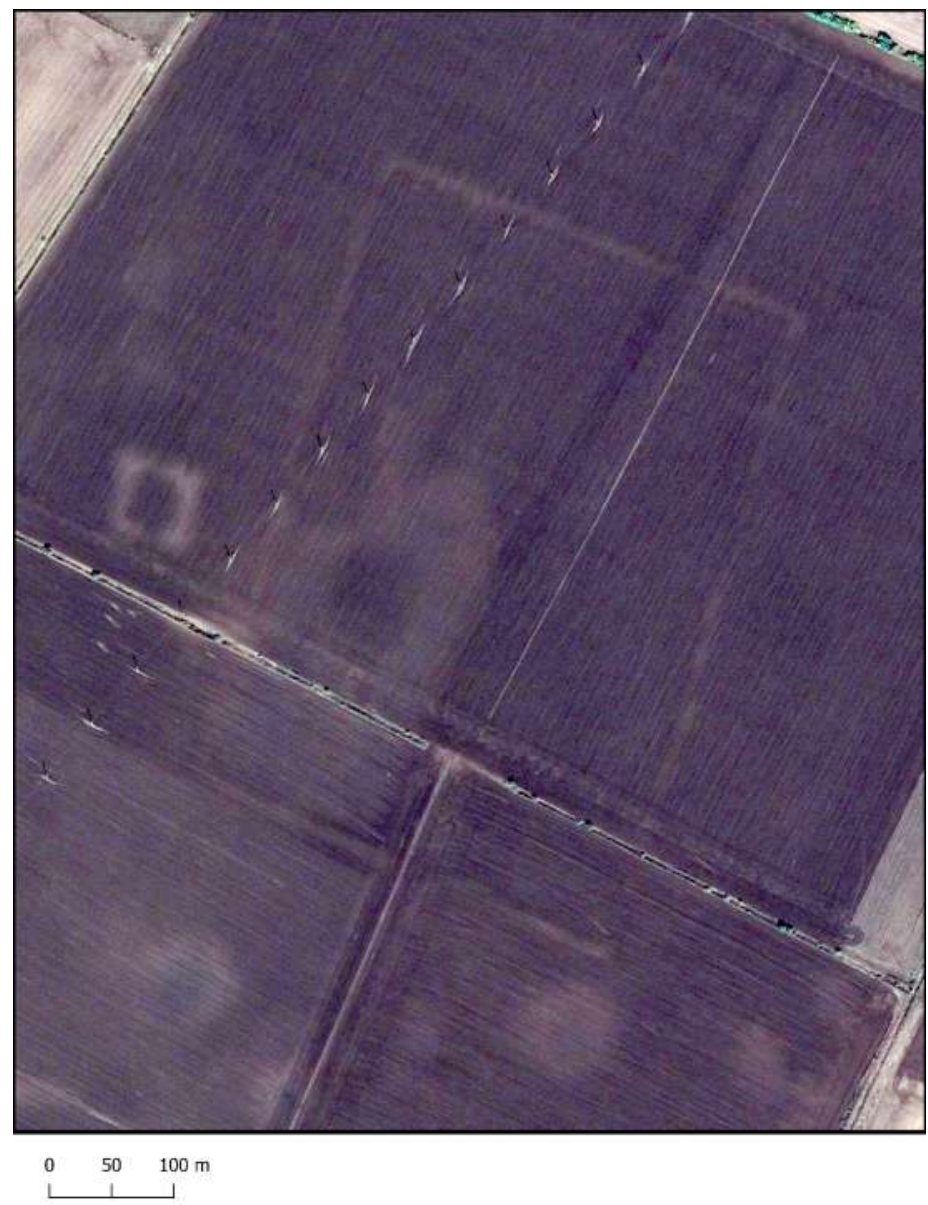

04. Vâlcele, localizarea fortificației, ortofotoplan Google Earth Satellite 2019.

O fortificație asemănătoare cu cea precedentă a fost semnalată pe imaginile aeriene la Mărculeşti-Gară (com. Perişoru, jud. Călăraşi). Aceasta a fost documentată încă din perioada interbelică de către P. Polonic ${ }^{16}$ (fig. 2). Fortificația are dimensiunile de $520 \times 350 \mathrm{~m}^{17}$ (18,2 ha), fiind orientată VNV-ESE (fig. 5-6). Pe suprafața puternic aplatizată, conturul dreptunghiular al fortificației se distinge ca o dungă deschisă la culoare ușor imprecisă pe fotograma Direcției Topografice Militare din 1953 (fig. 6.b), dar mult mai vizibilă decât pe cele recente (fig. 6.a). Nu se observă întreruperi care ar fi putut fi atribuite unor porţi și nici amprente mai închise la culoare care ar corespunde șanțului.

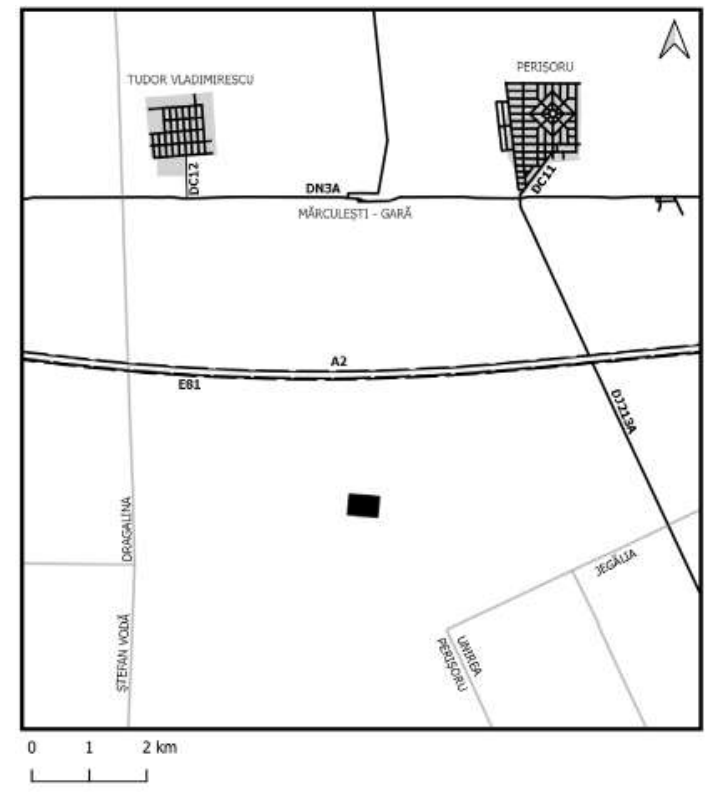

05. Perișoru - Gara Mărculești, localizarea fortificatiei.

6 Polonic 1935, fig. 2.

17 Condurăţeanu 2013, 55 fig. 13; 56. Dimensiunile date de autor în urma măsurătorilor între valuri sunt: 491 x 344 m; 16,89 ha. Dimensiuni măsurate de noi se raportează la mijlocul valurilor, aşa cum am procedat și în restul cazurilor prezentate. 

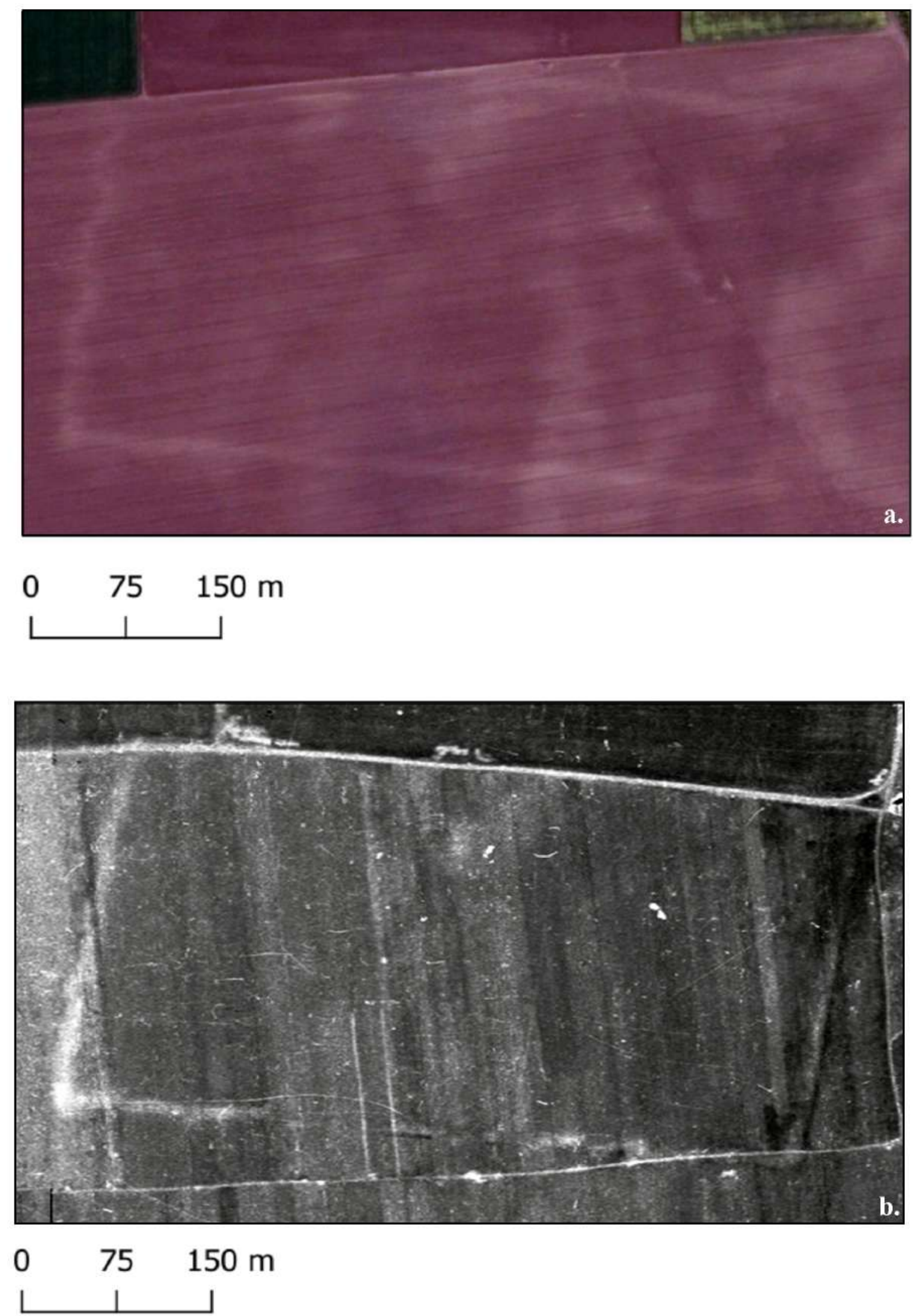

06. a. localizarea presupusei fortificații romane de la Perişoru-Movila Hotar la Cetăţuie, ortofotoplan Google Earth 2017; b. fotograma DTM (Direcția Topografică Militară) din 1954, serial\# 4998-54, sc. 1:20.000, georeferențiată Stereo70, GlobalMapper v22.1. Imagine reprodusă cu acordul scris al titularului drepturilor de autor, U.M. 02583 București, contract A6207/22.08.2019. 
Castrul de la Filipești (com. Surdila-Găiseanca, jud. Buzău) a fost semnalat, de asemenea, de către P. Polonic, care a ajuns la fața locului înainte de Primul Război Mondial când a identificat și descris ,castrul roman de la Filipeşti” (fig. 7-9). Pe baza acestor informaţii au fost efectuate mai multe încercări de identificare pe teren, însă deoarece urmele acestuia nu sunt vizibile la faţa locului (datorită lucrărilor agricole), localizarea a rămas neclară între satele Filipești şi Găiseanca. Fortificaţia se conturează după aliniamentul valului care se poate observa pe fotogramele efectuate de Direcţia Topografică Militară. din anul 1954 şi americană din 1966, sau cele de dată mai recentă (2019). Aceasta are formă dreptunghiulară, cu dimensiunile de $529 \times 355 \mathrm{~m}(18,7 \mathrm{ha})^{18}$, fiind orientată VSV-ENE (fig. 8 a-b). În fotografiile satelitare din anul 2019 (fig. 8.a), se pot observa detalii despre valul de apărare, mai deschis la culoare, dublat spre exterior de o dungă mai închisă care corespunde șanțului fortificației. Conturarea cu claritate a tuturor laturilor fortificaţiei a putut fi obținută în urma prelucrării fotogramei Direcției Topografică Militare din anul 1954. Observațiile par să fie confirmate și în prospecțiunile geofizice din anul $2019^{19}$. In urma interpretării fotografiilor oblice (fig. 9) și a modelului digital al terenului, nu au putut fi obținute informaţii suplimentare.

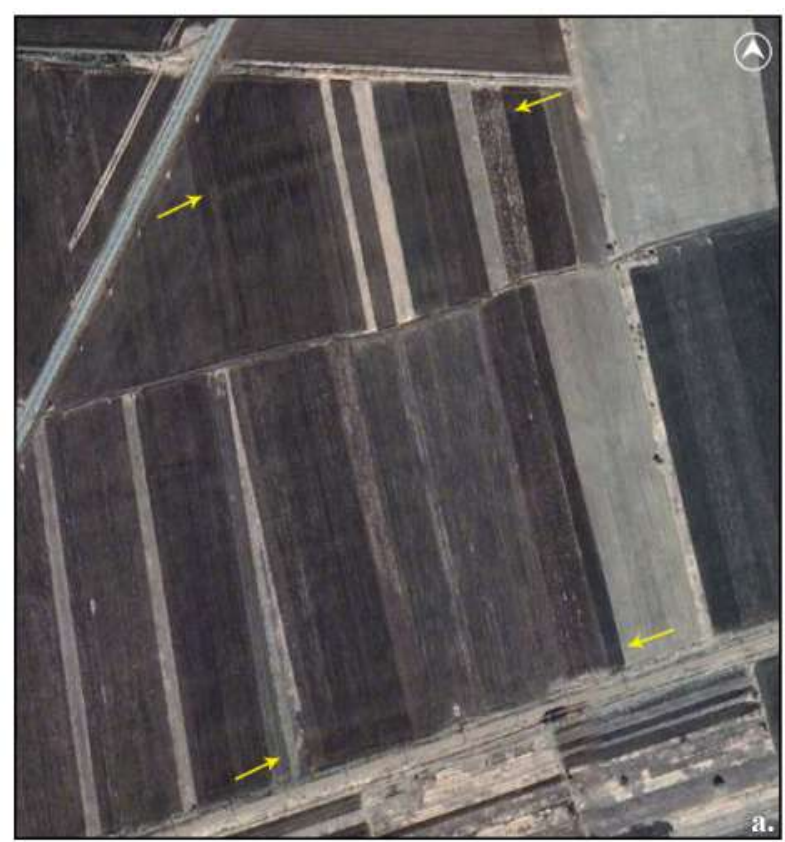

$0 \quad 75 \quad 150 \mathrm{~m}$

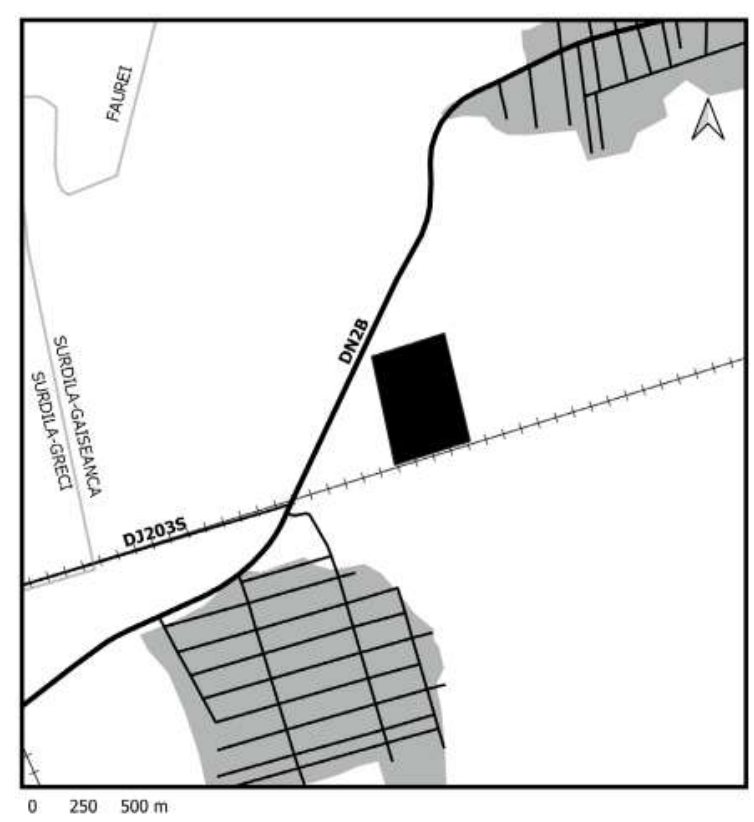

07. Filipești, localizarea fortificației.

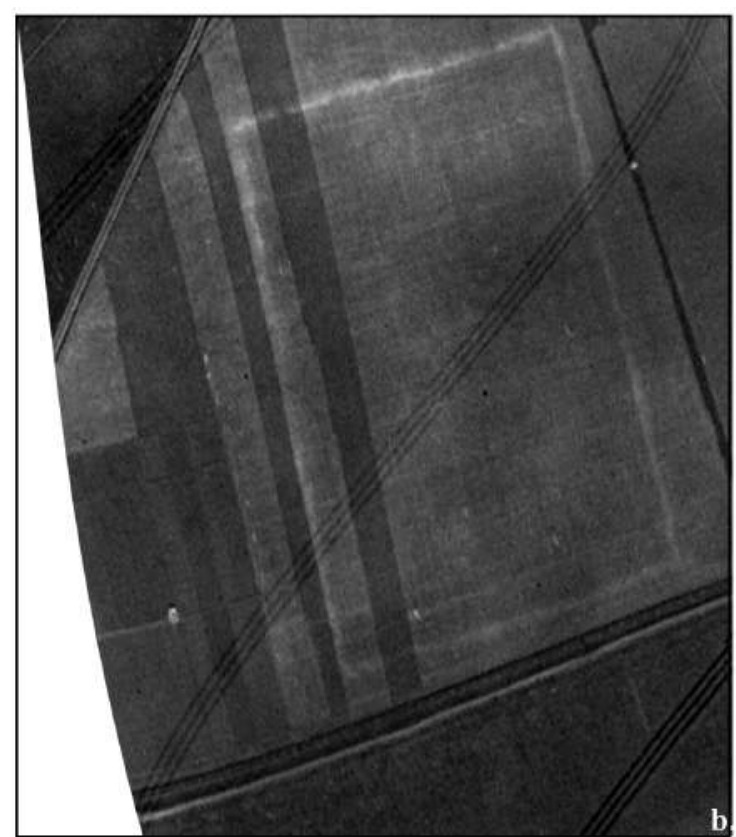

$0 \quad 75 \quad 150 \mathrm{~m}$

08. a. Filipești, ortofotoplan Google Earth Satellite 2019; b. presupusa fortificație romană de la Filipești, fotograma DTM (Direcția Topografică Militară) din 1954, serial\# 2354, sc. 1:20.000, georeferențiată Stereo70, GlobalMapper v22.1. Imagine reprodusă cu acordul scris al titularului drepturilor de autor, U.M. 02583 București, contract A6207/22.08.2019.

18 Condurățeanu 2014, 804 nota 26, 805, fig. 19.

19 http://obiectivbr.ro/content/descoperire-senza\%C5\%A3ional\%C4\%83 - accesat în 15.07.2021. 


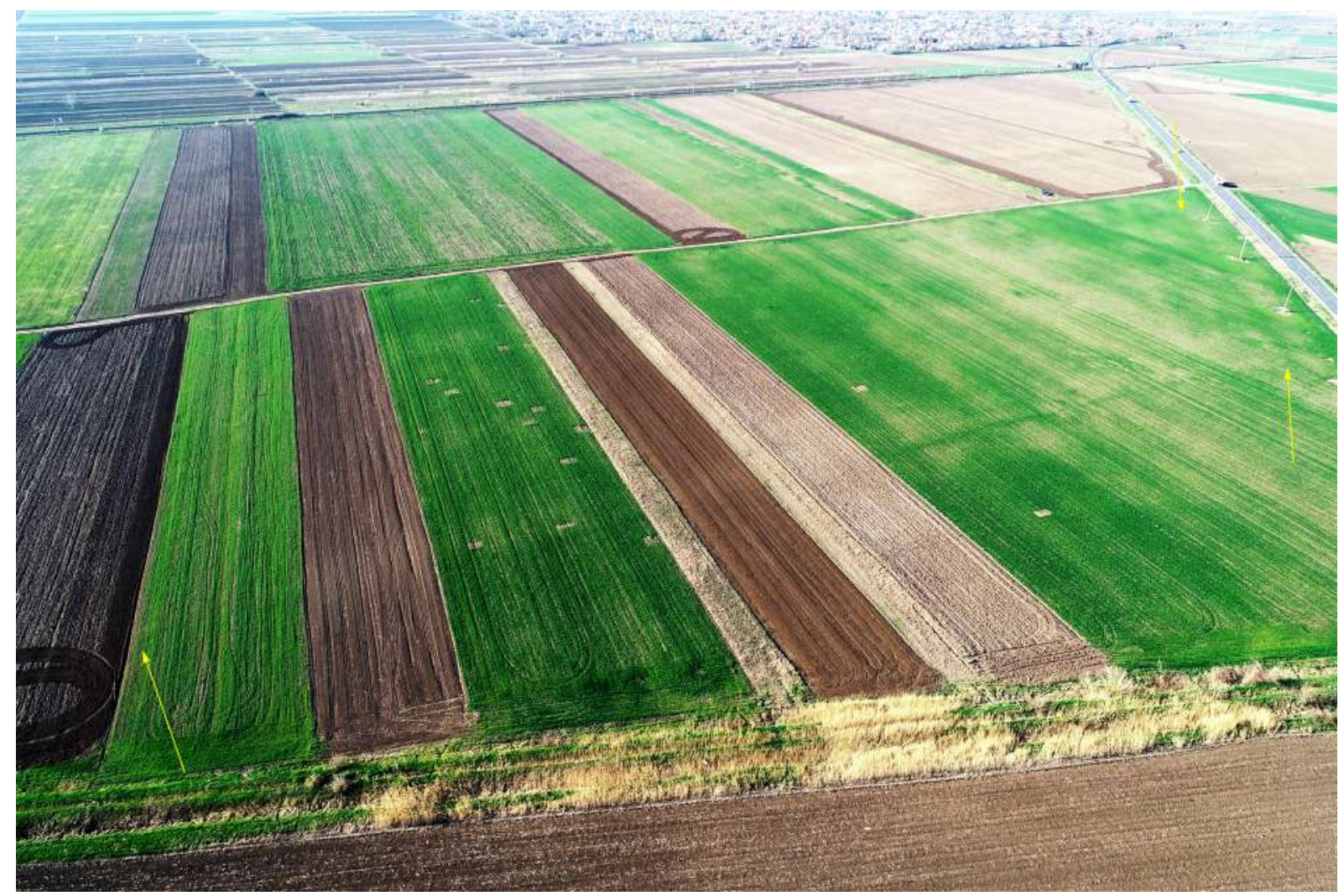

09. Filipești, fotografie oblică din dronă, vedere dinspre nord-vest (foto-Daniel Costea-Aprilie 2021).

O semnalare foarte recentă a fost făcută la Roșioru, com. Cochirleanca, jud. Buzău (fig. 10-12). La aproximativ $410 \mathrm{~m}$ Nord de sat a fost identificată o fortificație rectangulară, cu dimensiunile de 480 x 360 / 380 m, orientată NE-SE. La aproximativ 170 m Est față de această fortificație, se observă urmele unei fortificații secundare patrulatere cu dimensiunile de aprox. $65 \mathrm{x}$ 65 m, situație foarte asemănătoare cu cea de la Vâlcele. Informațiile au fost confirmate și prin fotografii oblice (fig. 12). Suprafața este puternic aplatizată din cauza lucrărilor agricole, iar latura sudică a fost distrusă de cursul pârâului Cochirleanca. Pe modelul digital al terenului nu au putut fi sesizate urme ale valului sau ale unor șanțuri. $\mathrm{Cu}$ toate acestea putem presupune că această structură provine de la conturul unui castru temporar, asemănător cu cele descrise mai sus. În cursul perieghezelor, pe o suprafață care depășește 100 ha, incluzând suprafața castrului, au fost identificate fragmente ceramice lucrate la roată, databile în secolele II-III p. Chr., respectiv IV p. Chr. (fragmente care pot fi atribuite culturii Sântana de Mureș - Cerneahov) $)^{20}$.

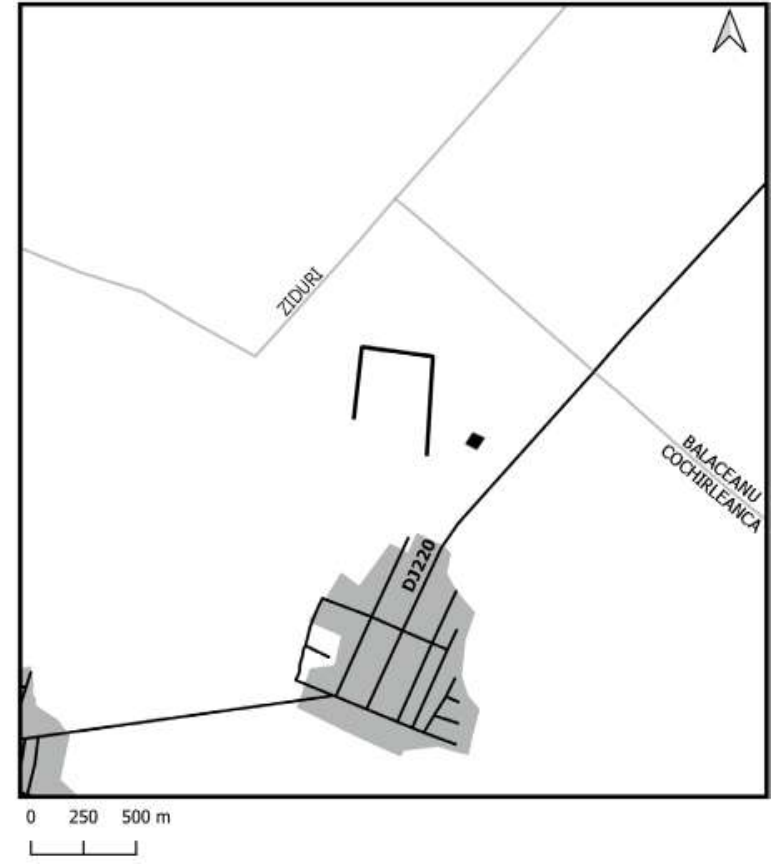

10. Roșioru, localizarea fortificației. 


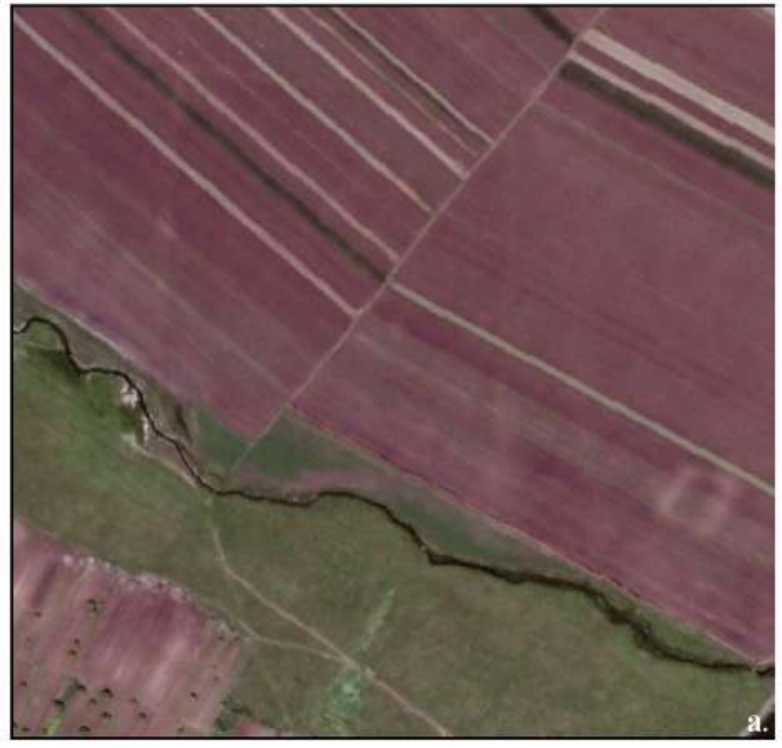

$075150 \mathrm{~m}$

11. a. Roșioru, ortofotoplan Google Earth Satellite 2015; b. fotografie declasificată satelit Corona 1968 (U.S. Geological Survey, 2008).

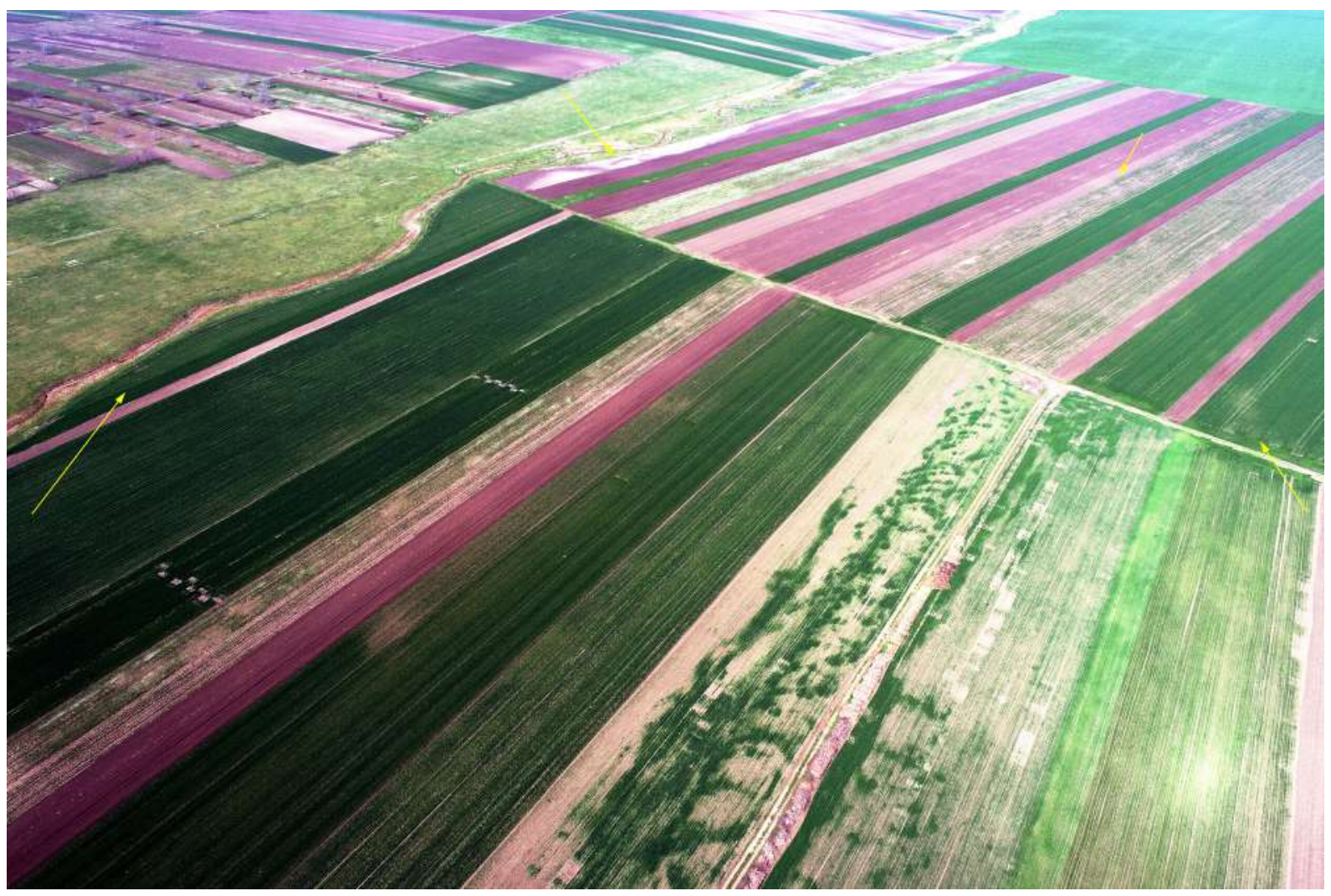

12. Roșioru, fotografie oblică din dronă, vedere dinspre est (foto - Daniel Costea - Aprilie 2021). 


\section{Observații finale}

După formă şi dimensiuni, castrele de la Vâlcele, Mărculeşti - Gară, Filipeşti și Roșioru sunt asemănătoare celor de la Istria, Ovidiu sau Căscioarele ${ }^{21}$. Nu au putut fi identificate întreruperi corespunzătoare unor porți, dar acest fapt poate fi explicat prin gradul relativ precar de păstrare a valurilor care delimitau aceste fortificații. Toate sunt în zone de câmpie în care agricultura se practică intensiv.

Dacă lungimea acestor castre este asemănătoare cu cea a castrului de la Durostorum $(510$ x 430 m; 21,9 ha), în privința lățimii avem de-a face cu un raport de 1:1,2 față de castrul amintit. Întrucât spațiul de acomodare din interiorul unui castru de marș este mai mare decât cel dintr-o garnizoană permanentă, putem presupune că în aceste castre au putut campa 2 sau 3 cohorte legionare. Cu un anumit grad de probabilitate, castrele amintite pot fi puse în legătură cu acțiuni ale unor efective ale legiunii XI Claudia din perioada staționării la Durostorum. Alte explicații privind datarea și funcționarea acestor presupuse fortificații rămân un deziderat pentru viitoare cercetări prin care pot fi obținute noi descoperiri și detalii.

\section{Appendices: Date despre documentarea a două fortificații de pe teritoriul Munteniei}

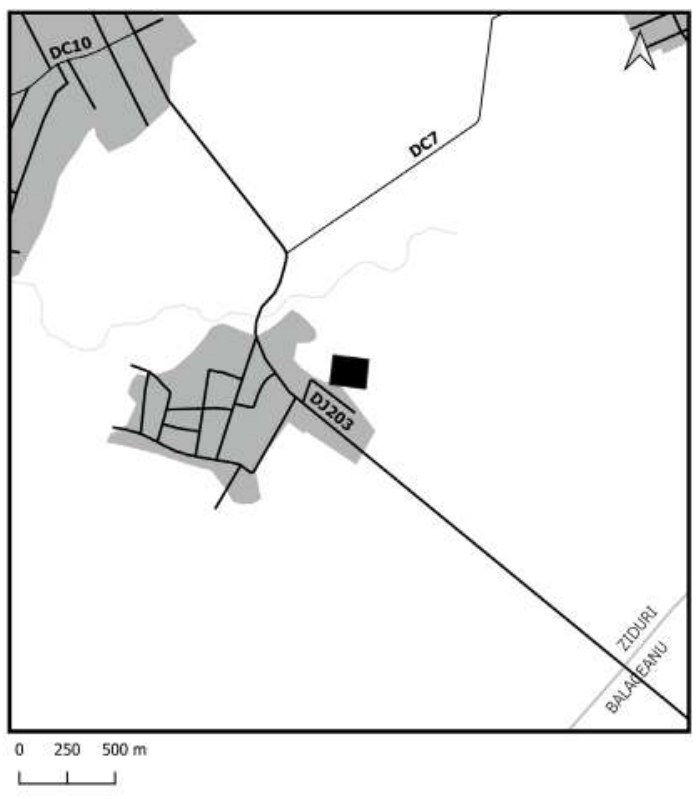

13. Lanurile, localizarea fortificației.
Vom aminti în final alte trei semnalări de pe teritoriul Munteniei, asupra cărora nu vom intra în detalii întrucât nu se încadrează în subiectul analizat până la obținerea unor date suplimentare:

În urma studierii detaliate a imaginilor satelitare de la Roșioru, am putut face unele observații privind anumite structuri rectangulare de pe teritoriul satului învecinat, Lanurile, com. Ziduri, jud. Buzău (fig. 13). La limita estică a acestuia, la aproximativ $250 \mathrm{~m}$ Sud-Vest de punctul marcat "Movila Bătrână" (fig. 14), a putut fi observată o structură rectangulară având următoarele dimensiuni: 180 m (latura nordică); 160 m (latura estică); 115 m (latura sudică); 105 m (latura vestică). Pe Planul Director de Tragere 4753 au fost marcate două incinte adosate care indică existența la acea dată a unor urme vizibile pe teren, informație confirmată parțial prin fotografii oblice (fig. 16). Suprafața este puternic aplatizată din cauza lucrărilor agricole. La suprafața solului și sau pe modelul digital al terenului nu au putut fi sesizate denivelări semnificative care să indice existența unui val sau a unor șanțuri (fig. 15). Nu putem formula vreo ipoteză privind tipologia acestei structuri.

14. Lanurile, localizarea fortificației pe Planul director de tragere, 4753, ridicare topografică 1895, corecturi parțiale până la 19.VII. 1940, nomenclatura după indicatorul alfabetic al localităților din 1954.

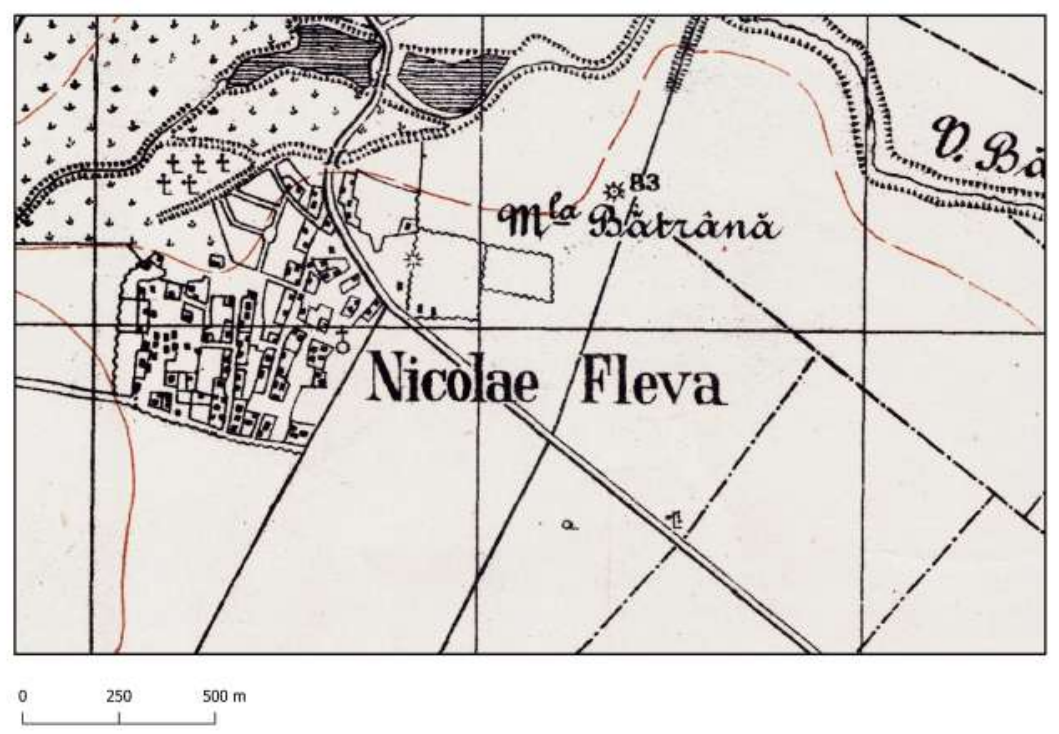

$\overline{21}$ Țentea et al. 2019, 69-75; Țentea și Matei-Popescu 2021, fig. 19. 


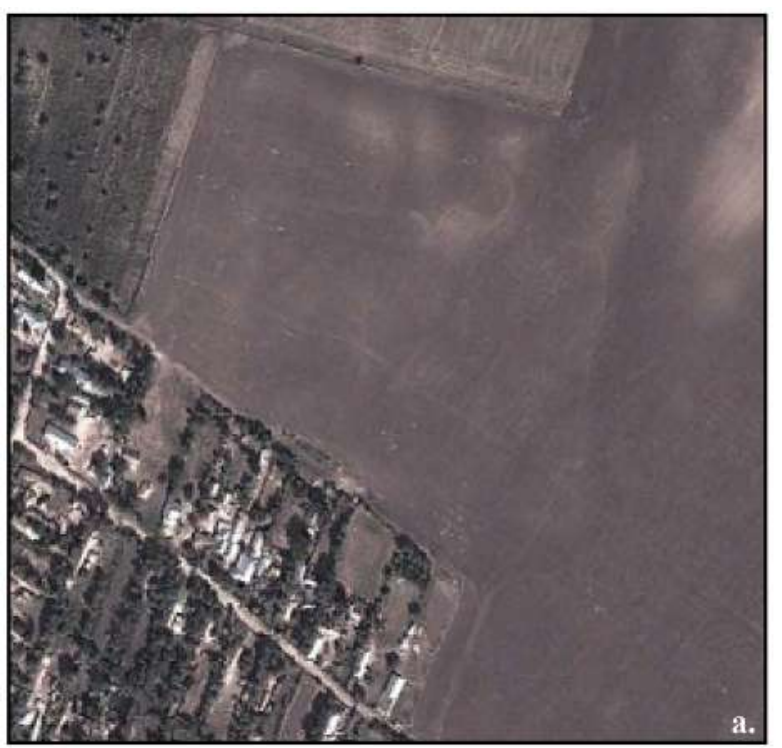

$0 \quad 2550 \mathrm{~m}$

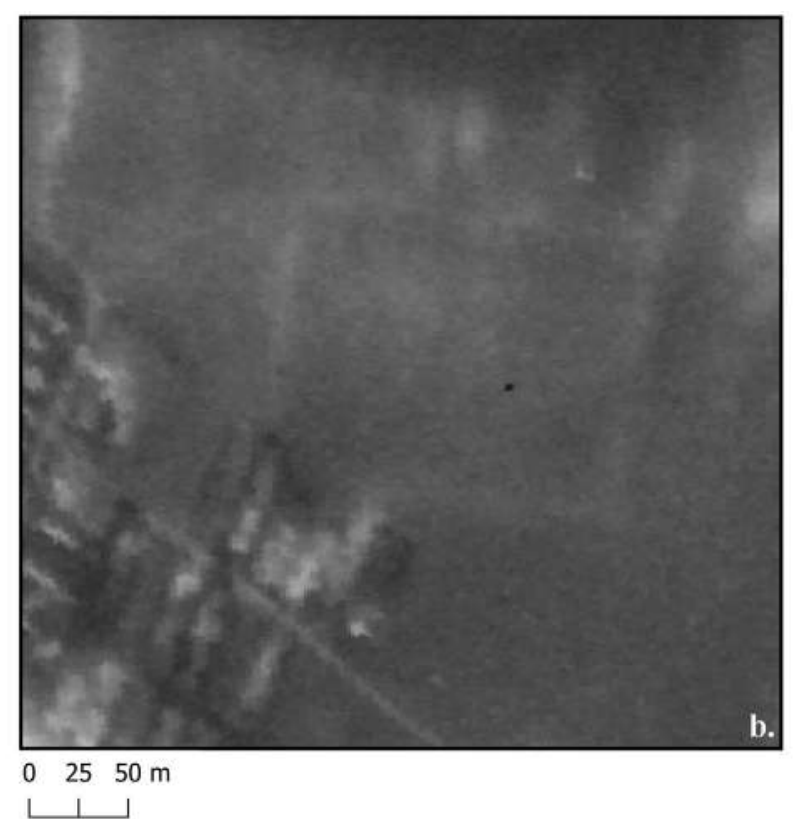

15. Lanurile, ortofotoplan Google Earth Satellite 2014; b. fotografie declasificată satelit Corona 1968 (U.S. Geological Survey, 2008)

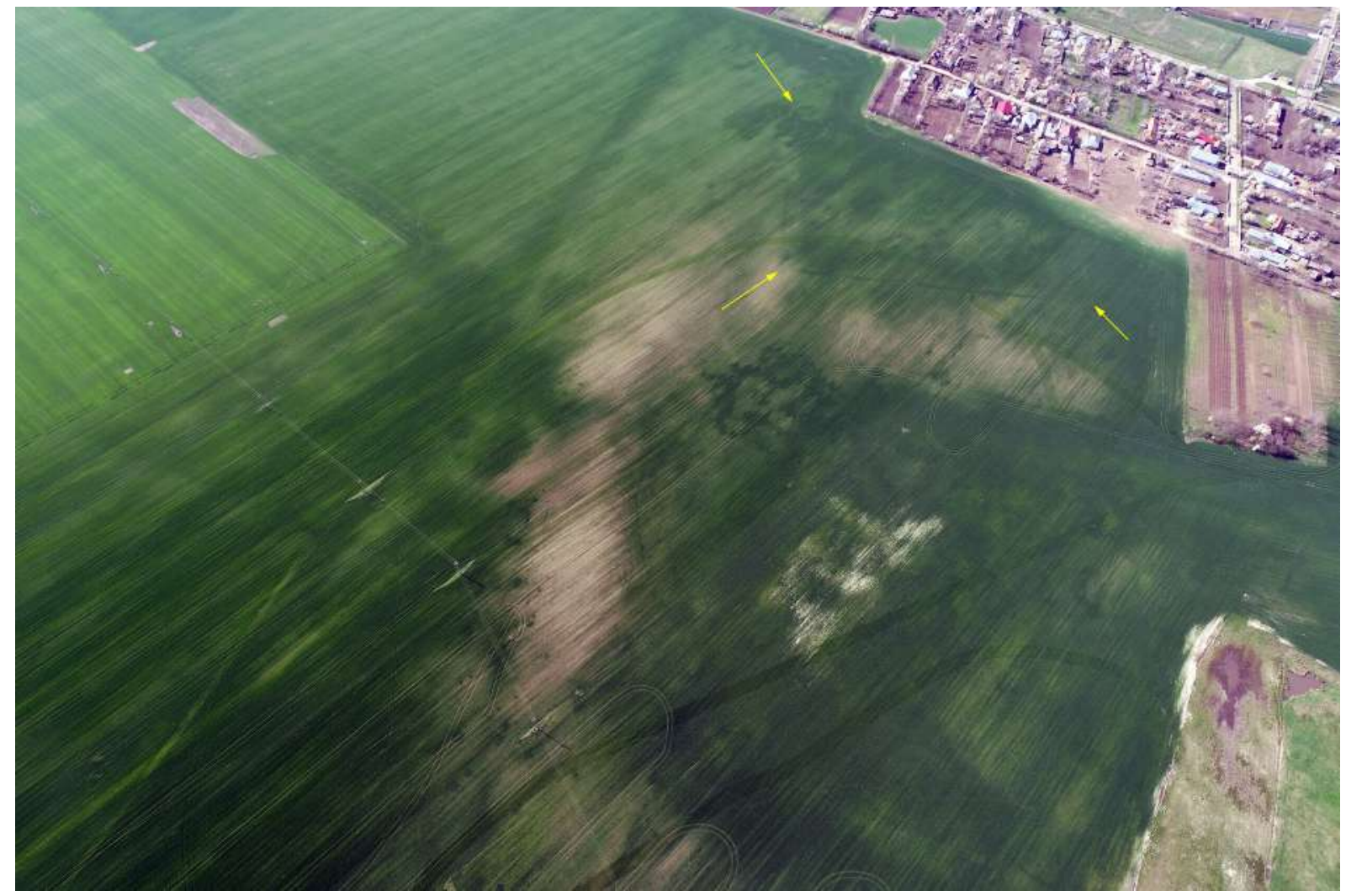

16. Lanurile, fotografie oblică din dronă, vedere dinspre nord-est (foto-Daniel Costea-Aprilie 2021). 
O fortificație dreptunghiulară $(116 \times 93$ m) a fost descoperită pe teritoriul oraşului Lehliu-Gară (jud. Călărași), punct Răzvani-Cetăţuie (fig. 17). Prima menţiune a acesteia apare într-un manuscris apartinând lui P. Polonic ${ }^{22}$. Aceasta a fost marcată ca o împrejmuire pe Planul Director de Tragere 4643 sub denumirea "Cetatea Fetei" (fig. 18). Conturarea sa a putut fi văzută pe fotograme aeriene: valul, mai deschis la culoare are o lățime de $13 \mathrm{~m}$, iar amprenta care conturează șanțul înconjurător este lată de 10 m (fig. 19). Dimensiunile mici ale fortificației fac foarte dificilă atribuirea funcționalității, fiind necesară colectarea unor informații suplimentare.

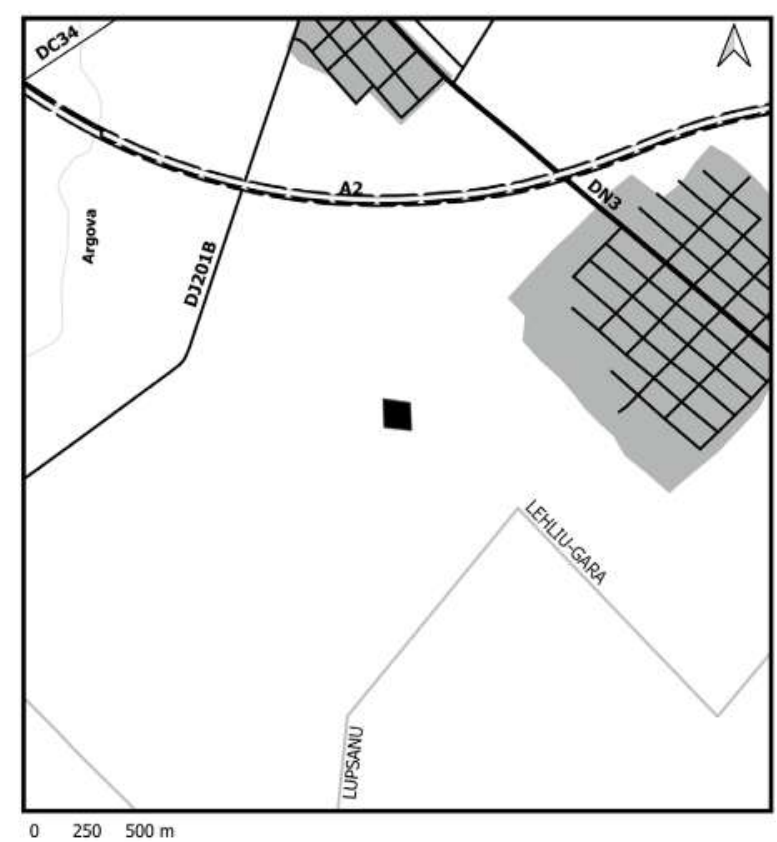

17. Lehliu - Gară, localizarea fortificației.

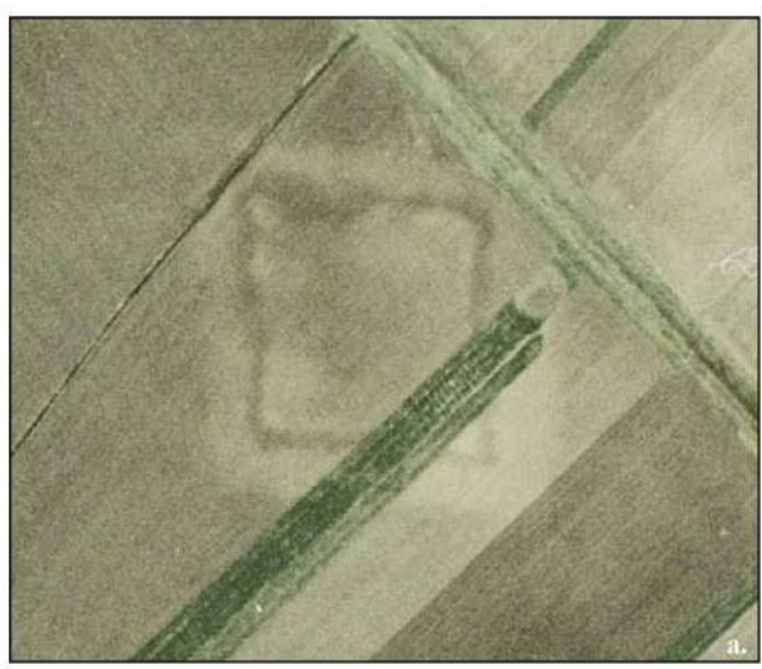

$0 \quad 2550 \mathrm{~m}$

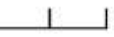

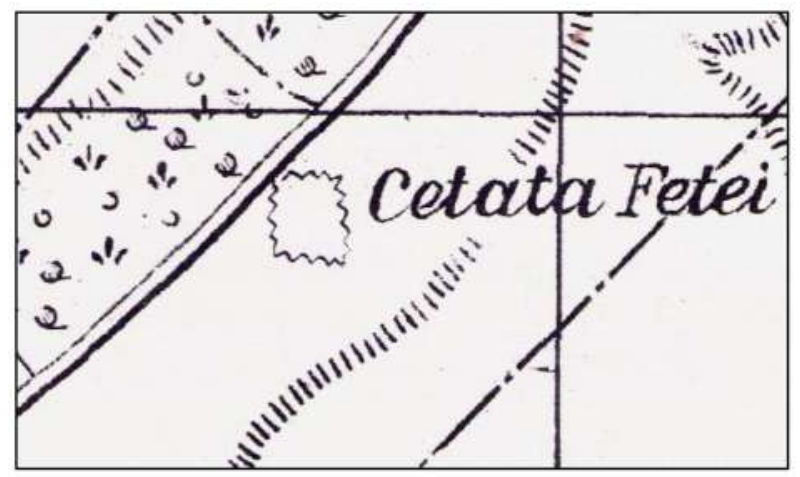

18. Lehliu - Gară, localizarea fortificației pe Planul director de tragere, 4643, ridicare topografică 1908, nomenclatura după indicatorul alfabetic al localităţilor din 1956.

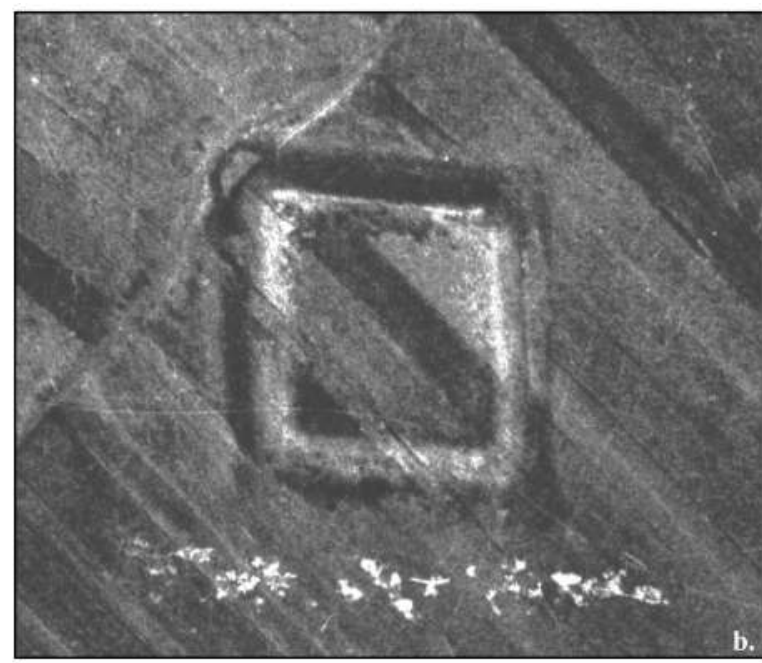

$0 \quad 2550 \mathrm{~m}$

19. Lehliu - Gară, a. Răzvani - Cetățuie, localizarea fortificației, fotografie aeriană Lehliu - Gară 2003; b. presupusa fortificație romană de la Răzvani-Cetăţuie/Cetatea Fetei, fotograma DTM (Direcția Topografică Militară) din 1953, serial\# 30709-53, sc. 1:20.000, georeferențiată Stereo70, GlobalMapper v22.1. Imagine reprodusă cu acordul scris al titularului drepturilor de autor, U.M. 02583 București, contract A6207/22.08.2019.

22 Polonic 1927: “La 5 km spre S.V. de satul Valea Seacă [sat dispărut în zilele noastre, care se afla în trecut între Răzvani şi Nucetu] "Cet. Fetei"”'. Fortificaţia este descrisă în literatura de specialitate drept "o fortificaţie de pământ, astăzi Cetatea Fetei sau Cetăţuia, cu şanț, atribuită cu titlul de ipoteză epocii romane”, cf. TIR L35, p. 61 
O fortificație rectangulară cu zidărie de piatră a fost presupusă de P. Polonic pe un grind aflat la Sud de satul Ciocănești (Călăraşi), într-un loc necercetat arheologic ${ }^{23}$.
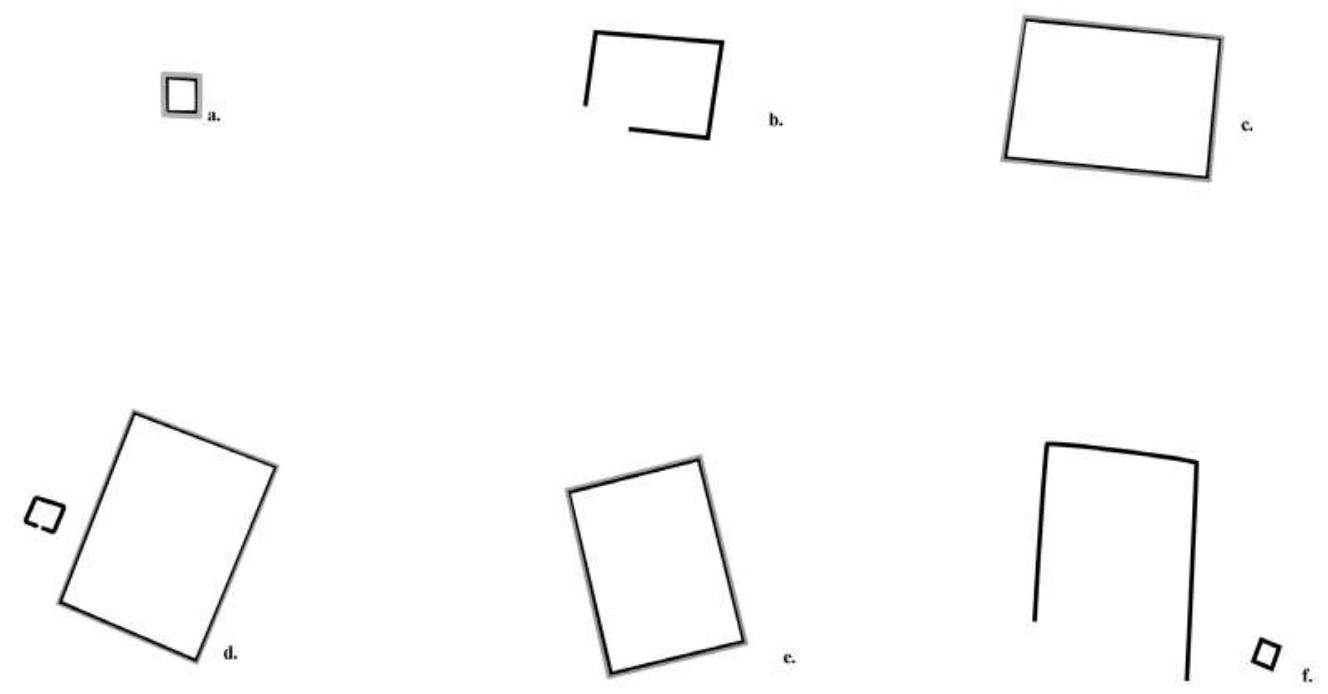

$800 \mathrm{~m}$

20. Planurile fortificaților romane menționate: $a$. Răzvani, b. Lanurile, c. Gara-Mărculești, d. Vâlcele, e. Filipești, f. Roșioru

\section{BIBLIOGRAFIE}

Bârcă, V. 2020. Funerary Ditched Enclosures in the Sarmatian Funerary Ritual. Observations Regarding Their Introduction, Distribution, Use, and Dating. Ziridava 34: 325-376.

Bogdan-Cătăniciu, I. 1974. Cercetări în Castellum de la Rucăr. Studii și Cercetări de Istorie Veche și Arheologie 25/2: 277-288.

Condurăţeanu, B. 2013. Sigiliul Romei în România - Recompunerea oglinzii sparte a Crăiesei Zăpezii. Un studiu topografic într-o abordare multidisciplinară cu ecouri într-un hartă de navigație GPS a României. În Colocviul Internațional Comunicare și Cultură în România Europeană, Ediția a II-a: Antichitate și (post)modernitate: paradigme evolutive în România, 24-25.09.2013, Timişoara, Vol. 1: 32-64. Szeged: JATEPress Kiadó.

Condurăţeanu, B. 2014. Opening a window into Romania's distant past with the help of declassified American Cold War spy aircraft imagery. Episode 1. The Roman legion castra from Filipești and the Roman forts and Limes Transalutanus from Albota, Piteşti and Mărăcineni. In. Forțiu, S. and Cîntar, A. eds. ArheoVest, Nr. II: In Honorem Gheorghe Lazarovici, Interdisciplinaritate in Arheologie, Timișoara, 6 decembrie 2014, Vol. 2: Metode Interdisciplinare, Asociația „ArheoVest” Timișoara: 793-820. Szeged: JATEPress Kiadó.

Condurățeanu, B. 2017. Roman Fortresses and Sites along the Lower Danube: Reconsidering a Nineteenth Century Source in the Light of Modern Cartography and Satellite Imagery, in: De Sena, E. and Timoc, C. (eds.) Romans in the Middle and Lower Danube Valley, 1st century BC-5th century AD. Case Studies in Archaeology, Epigraphy and History (British Archaeological Reports. International Series 2882): 61-82. Oxford: BAR Publishing.

23 Măgureanu 2014, 119-120, fig. 1; Condurățeanu 2017, 67; Zahariade 2018, 133-134. Pentru localizare vezi fig. 2, prelucrată după Polonic 1935, 21. 
Constantinescu, E. M. 1999. Memoria Pâmântului dintre Carpați și Dunăre. Nord-estul Munteniei şi sud-vestul Moldovei în veacurile IV-XI d.Hr. Bucureşti: Fiat Lux.

Dinu, C., Garvăn, D., Matei, S. și Munteanu, R. 2017. Contribuţii la repertoriul arheologic al judeţului Buzău. Cercetări de suprafaţă pe teritoriul comunei Cochirleanca. Mousaios 21: 173-175.

Jones, R. H. 2017. What is a Roman camp? In. Hodgson, N, Bidwell, P and Schachtmann, J (eds) Roman Frontier Studies 2009. Proceedings of the XXI International Congress of Roman Frontier Studies (Limes Congress) held at Newcastle upon Tyne, August 2009: 521-530, Oxford: Archaeopress.

Măgureanu, D. 2014. The time and works of Pamfil Polonic. Caiete ARA 5: 115-126.

Mrdić, N. and Milovanović, B. 2017. Viminacium - Roman City and Legionary Camp: Topography, In Hodgson. N., Bidwell P., Schachtmann, J., Evolution and Urbanism, Roman Frontier Studies 2009: Proceedings of the XXI International Congress of Roman Frontier Studies (Limes Congress) held at Newcastle upon Tyne, August 2009: 393-400. Oxford: Archaeopess.

Oltean, I. A. and Hanson W. S 2015. Defining the Roman Limes in Romania: the Contribution of Aerial and Satellite Remote Sensing. : In . L. Vagalinski and N. Sharankov (eds.) Proceedings of the 22nd International Congress of Roman Frontier Studies, Ruse, Bulgaria, September 2012: 889-900. Sofia: Bulletin of the National Archaeological Institute XLII.

Petolescu, C. C. 1986. Les camps de la zone sud-carpatique de la Dacie, In: Unz, C. (Hrsg.) Studien zu den Militärgrenzen Roms III. Akten des 13. Internationalen Limeskongresses Aalen 1983. Vorträge: 510-514. Stuttgart: Konrad Theiss Verlag.

Petrescu, F. 2002. Repertoriul monumentelor arheologice de tip Sântana de Mureș-Cerneanhov de pe teritoriul României. București: Ars Docendi.

Polonic P. 1927 Mapa nr. 03, Plic IX_Manuscrise Pamfil Polonic-1927, Ms nr.IX_caiet1_note de locuri istorice, p. 8, mss. Biblioteca Academiei Române.

Polonic, P. 1935. Cetățile antice de pe malul drept Dunării (Dobrogea) până la gurile Dunării, Natura 18-26.

Ștefan, D. și Ștefan, M. 2018. Teledetecție și arheologie montană în Carpații de Curbură. Fortificațiile de la Vârful lui Crai. Istros 24: 219-288.

TIR L 35. Tabula imperii romani: Romula - Durostorum - Tomis; sur la base de la carte internationale du monde a l'échelle de 1:1.000.000. Bucarest: Academie de la République Socialiste de Roumaine 1969.

Țentea, O., Opriș, I. C., Matei-Popescu, Fl., Rațiu, Al., Băjenaru, C., Călina, V. 2019. Frontiera romană din Dobrogea. O trecere în revistă și o actualizare. Cercetări arheologice 26: 9-82.

Țentea, O. și Matei-Popescu, Fl. 2015. Why there? The preliminaries of constructing the Roman Frontier in SouthEast Dacia. Acta Musei Napocensis 52/1: 109-130.

Țentea, O. și Matei-Popescu, Fl. 2021. Roman Camps in the Lower Danube area: from remote sensing to provincial context, In: J. Karavas, E. Handscam. The Roman Lower Danube Frontier: Innovations in Theory and Practice”. Oxford: BAR Press (forthcoming).

Zahariade, M. și Dvorski, T. 1997. The Lower Moesian Army in Northern Walachia (A.D. 101-118). An Epigraphical and Historical Study on The Brick and Tile Stamps Found in The Drajna de Sus Roman Fort. Bucureşti: Editura Glykon \& Fortuna.

Zahariade, M. 2018. New Thoughts on old Subjects: the Romans in the Sub-Carpathian Area in A.D. 101-106. With a Hawkish Eye on the Role of the Drajna de Sus Roman Camp. In. Petolescu, C. C., Galinier, M., MateiPopescu, Fl. eds. Divus Traianus: travaux du colloque international de Drobeta-Turnu Severin, 16-17 Juin 2017 : 127-145. Bucureşti: Editura Academiei Române.

\section{ILLUSTRATIONS}

01. Map of presumed roman fortifications in Muntenia.

02. Pamfil Polonic's map superimposed on digital elevation model (Polonic, P., Cetățile antice de pe malul drept al Dunării (Dobrogea) până la gurile ei, În: Revista „Natura”, nr. 7, 15 iulie 1935, pg. 21).

03. Vâlcele, fort location. 
04. Vâlcele, site location on Google Earth Satellite Image 2019.

05. Perișoru - Gara Mărculești, fort location.

06. a. presumed roman fortification from Perişoru - Movila Hotar la Cetăţuie on Google Earth Satellite Image 2017; b. The layout of the presumed roman fortification from Perişoru-Movila Hotar la Cetăţuie, from the 1954 DTM photogram, serial\# 4998-54, sc. 1:20.000, georeferenced Stereo70, GlobalMapper v22.1. Image reproduced with the written permission of the copyright owner, U.M. 02583 Bucharest, contract A6207/22.08.2019.

07. Filipești, fort location.

08. a. Filipești, site location on Google Earth Satellite Image 2019; b. Layout of the presumed roman fortification from Filipeşti from the 1954 DTM (Direcţia Topografică Militară) photogram, serial\# 23-54, sc. 1:20.000, georeferenced Stereo70, GlobalMapper v22.1. Image reproduced with the written permission of the copyright owner, U.M. 02583 Bucharest, contract A6207/22.08.2019.

09. Filipești, oblique drone photograph, northwest view (April 2021).

10. Roșioru, fort location.

11. Roșioru, a. site location on Google Earth Satellite Image 2015; b. declassified 1968 Corona satellite photo (U.S. Geological Survey, 2008).

12. Roșioru, oblique drone photograph, east view (April 2021).

13. Lanurile, fort location.

14. Lanurile, the layout of enclosures near the present village of Lanurile as shown on the 4753 Firing Directory Plan, topographical survey 1895, partial corrections until 19.VII. 1940, nomenclature according to the alphabetical index of localities from 1954.

15. Lanurile, a. site location on Google Earth Satellite Image 2014; b. declassified 1968 Corona satellite photo (U.S. Geological Survey, 2008).

16. Lanurile, oblique drone photograph, northeast view (April 2020).

17. Lehliu - Gară, fort location.

18. Lehliu - Gară, the layout and name of the Lehliu - Gară, Răzvani fortification as shown on the 4643 firing directory plan, topographical survey 1908 , nomenclature according to the alphabetical index of localities from 1956.

19. a. The Răzvani-Cetăţuie fortification on the 2003 Lehliu-Gară aerial photogram; b. The layout of the presumed Roman fortification from Răzvani-Cetăţuie/Cetatea Fetei as captured by the 1953 DTM (Direcţia Topografică Militară) photogram, serial\# 30709-53, sc. 1:20.000, georeferenced Stereo70, GlobalMapper v22.1. Image reproduced with the written permission of the copyright owner, U.M. 02583 Bucharest, contract A6207/22.08.2019.

20. Plans of mentioned Roman fortifications.

*The drone images $(09,12,16)$ were taken by Daniel Costea.

OVIDIU ȚENTEA

Muzeul Național de Istorie a României ovidiu.tentea@gmail.com

VLAD CĂLINA

Muzeul Național de Istorie a României calina.nicolae@gmail.com

BOGDAN CONDURĂȚEANU Universitatea 1 Decembrie 1918 Alba Iulia condurateanu.marian.sdi20@uab.ro

GEANINA BUTISEACĂ

Senckenberg Forschungsinstitut und Naturmuseum Senckenberganlage, Frankfurt, Deutschland butiseacageanina@gmail.com 